\title{
Extração de DNA de materiais de arquivo e fontes escassas para utilização em reação de polimerização em cadeia (PCR)
} Methods of DNA extraction from archived materials and rare sources for utilization in polymer chain reaction

Jaqueline A. Barea ${ }^{l}$

Maria Inês M. C. Pardini ${ }^{2}$

Tsieko Gushiken ${ }^{3}$

\begin{abstract}
Este trabalho visou a comparação de cinco métodos diferentes de extração de DNA de materiais de arquivo (tecidos incluídos em parafina, esfregaços de sangue periférico - corados e não corados com Leishman, lâminas com mielogramas, gotas de sangue em Guthrie Card) e de fontes escassas (células bucais, um e três bulbos capilares e $2 \mathrm{~mL}$ de urina), para que fossem avaliadas a facilidade de aplicação e a facilidade de amplificação deste DNA pela técnica da reação de polimerização em cadeia (PCR). Os métodos incluíram digestão por proteinase K, seguida ou não por purificação com fenol/clorofórmio; Chelex 100® (BioRad); Insta Gene ${ }^{\circledR}$ (BioRad) e fervura em água estéril. O DNA obtido foi testado para amplificação de três fragmentos gênicos: Brain-derived neutrophic factor (764 pb), Factor V Leiden (220 pb) e Abelson (106 pb). De acordo com o comprimento do fragmento gênico estudado, da fonte potencial de DNA e do método de extração utilizado, os resultados caracterizaram o melhor caminho para padronização de procedimentos técnicos a serem incluidos no manual de Procedimentos Operacionais Padrão do Laboratório de Biologia Molecular do Hemocentro - HC - Unesp - Botucatu. Rev. bras. hematol. hemoter. 2004;26(4):274-281.
\end{abstract}

Palavras-chave: Materiais de arquivo; fontes escassas; extração de DNA; PCR.

\section{Introdução}

A reação de polimerização em cadeia (PCR) é uma técnica rápida que permite a amplificação de regiões do genoma, a partir de mínimas quantidades de DNA, mesmo que degradado. ${ }^{1}$ Em vista disso, torna-se uma metodologia de escolha para a utilização em tecido fixado em formalina e incluído em blocos de parafina, ${ }^{2}$ além de outros materiais de arquivo e de fontes escassas de DNA.

Os materiais de arquivo constituem-se basicamente

\footnotetext{
${ }^{I}$ Mestre em Fisiopatologia em Clínica Médica; Área de Concentração: Metabolismo e Nutrição. Depto. Clínica Médica,

Faculdade de Medicina de Botucatu - Unesp.

${ }^{2}$ Pesquisadora do Departamento de Clínica Médica e responsável pelo Laboratório de Biologia Molecular do Hemocentro,

Faculdade de Medicina de Botucatu-Unesp.

${ }^{3}$ Mestre em Biologia Celular e Molecular pelo Instituto de Biociências da Unesp de Rio Claro, SP. Bióloga do Hemocentro,

Faculdade de Medicina de Botucatu - Unesp.
}

Local de Realização da Pesquisa: Laboratório de Biologia Molecular do Hemocentro de Botucatu - Faculdade de Medicina de Botucatu-Unesp.

Correspondência para: Jaqueline A. Barea

Laboratório de Biologia Molecular - Hemocentro de Botucatu

Faculdade de Medicina de Botucatu - Unesp

Rubião Júnior, $s / n^{\circ}$ -

18618-000-Botucatu-SP

Telefone/FAX: (14) 3811 -6041-e-mail: jaquelinebarea@laser.com.br 
de tecidos congelados ou fixados e incluídos em parafina; lâminas de mielograma, de esfregaço de sangue periférico, de análises citogenéticas, de exames ginecológicos preventivos; gotas de sangue em papel de filtro, etc. Tais materiais encontram-se arquivados nos diferentes serviços de um hospital, por meses, até anos, permitindo estudos retrospectivos ${ }^{3}$ e constituindo uma vasta fonte de tecidos humanos bem caracterizados. ${ }^{4}$

As fontes escassas de DNA podem ser fios de cabelo, gotas de esperma, resquícios de saliva, restos celulares em dentes arrancados ou sob unhas, sangue, ossos e tecidos de cadáveres decompostos; escarro, suco pancreático, bile e outros fluidos corpóreos que possam ser congelados e guardados, ou encontrados em diferentes situações.

Pesquisar métodos alternativos de extração de DNA que possam ser rápidos, práticos, baratos, livres de contaminação e de toxicidade e eficazes no que tange à quantidade, qualidade e possibilidade de amplificação por PCR, do DNA extraído, pode possibilitar a aplicação da pesquisa em outros estudos, como diagnósticos retrospectivos, identificação de indivíduos, estudos populacionais, envios de amostras à distância e aplicações na Medicina Forense.

Neste artigo, apresenta-se um estudo desenvolvido no Laboratório de Biologia Molecular do Hemocentro de Botucatu, onde cinco métodos de extração de DNA foram escolhidos, adaptados e aplicados em alguns materiais de arquivo e fontes escassas, de forma a serem eleitos os mais adequados para cada tipo de fonte potencial de DNA.

\section{Casuística e Métodos}

Todos os passos deste estudo passaram por apreciação e tiveram aprovação do Comitê de Ética do Hospital das Clínicas de Botucatu - Unesp

\section{Obtenção das amostras}

Os doadores voluntários de materiais frescos receberam as informações necessárias sobre a natureza da pesquisa e assinaram termo de consentimento esclarecido enquanto os materiais de arquivo utilizados foram obtidos junto aos serviços existentes no HC-Unesp Botucatu, mediante autorização do Conselho de Ética e dos responsáveis pelos serviços. Deu-se preferência para materiais excedentes do arquivo, que possuíssem réplicas em melhor estado.

\section{Pré-tratamentos para a Extração de DNA Materiais de Arquivo}

a) tecidos incluídos em parafina:

O pré-tratamento baseou-se na desparafinização prévia à extração de DNA e reidratação com duas lavagens subseqüentes com $0,5 \mathrm{~mL}$ de álcool etílico absoluto cada. ${ }^{5,6,7}$

b) esfregaços de sangue periférico corados e não corados com Leishman:

O pré-tratamento consistiu na raspagem do esfregaço, com lâmina de bisturi, para dentro de tubos tipo Eppendorf, onde se procedia a extração de DNA. ${ }^{8,9}$ Observa-se que, no caso das lâminas coradas, havia óleo mineral sobre elas, o que tornou necessária uma pré-lavagem em xilol histológico para sua eliminação.

c) gotas de sangue em Guthrie Card:

Seguindo as orientações de autores, ${ }^{10,11} 1 / 4$ de cada gota de sangue colhida no Guthrie Card foi recortada com uma tesoura desinfetada e colocado dentro do tubo tipo Eppendorf de 1,5 mL para os testes de extração e amplificação.

\section{Fontes Escassas de DNA}

a) bulbos capilares:

Provenientes de um e três fios de cabelos, que foram retirados com pinça e depois cortados a $1 \mathrm{~cm}$ a partir do bulbo e colocados dentro de tubos tipo Eppendorf, de 1,5 $\mathrm{mL}$.

Como foi observado que grande quantidade de sebo envolvia os bulbos capilares, foi padronizado lavá-los com $500 \mu$ L-1 mL de solução TKM-1 (10 mM Tris-HCl pH 7,6; $10 \mathrm{mM} \mathrm{KCl} ; 10 \mathrm{mM} \mathrm{MgCl}_{2} ; 2 \mathrm{mM}$ EDTA), na qual foram deixados por dez minutos, à temperatura ambiente e, após centrifugação a 10.000 rpm, por cinco minutos, a solução foi retirada com pipeta e descartada.

b) células bucais colhidas com swab:

Após a coleta das células bucais pelo pesquisador ou pelo doador, ${ }^{12,13}$ a haste do $s w a b$ foi descartada e a parte coletora foi acondicionada em tubos tipo Eppendorf de $1,5 \mathrm{~mL}$, onde se sucederam os testes de extração de DNA.

c) sedimentos obtidos a partir de urina:

A urina era coletada em tubos Falcon, de $50 \mathrm{~mL}$ e os testes de extração de DNA foram realizados a partir de alíquotas de $35 \mathrm{~mL}, 2 \mathrm{~mL}$ e $1 \mathrm{~mL}$ de urina, e foi determinado que as alíquotas de $2 \mathrm{~mL}$ eram ideais para este estudo.

Após inversões repetidas do tubo Falcon, alíquotas de $2 \mathrm{~mL}$ foram retiradas com pipeta automática ou de vidro e colocadas em tubos tipo Eppendorf de 2,0 mL. Após cinco minutos de centrifugação a $14.000 \mathrm{rpm}$, o sobrenadante foi descartado e o botão de células lavado com 0,5 a 1 mL de solução TKM-1.

A urina utilizada, ao ser estocada na geladeira, apresentava consistência alterada e formação de uma série de precipitados, que foram dissolvidos em banho-maria a $37^{\circ} \mathrm{C}$.

Outros autores apresentam diferentes métodos de extração de DNA de urina, diferentes dos aqui descritos. ${ }^{14,15}$ 


\section{Métodos de Extração de DNA}

Método 1 - digestão por proteinase K seguida por fenol e clorofórmio

Foram acrescidos $98 \mu \mathrm{L}$ de tampão de digestão (10 mM Tris-HCl a 0,1 M; 10 mM de EDTA a 0,2 M) e $2 \mu \mathrm{L}$ de proteinase $\mathrm{K}$ a $20 \mathrm{mg} / \mathrm{mL}$; seguiu-se incubação em banhomaria a $56^{\circ} \mathrm{C}$, por três horas. Após, inativação da proteinase $\mathrm{K}$ por fervura em banho-maria, a $100^{\circ} \mathrm{C}$ por oito minutos .

A precipitação do DNA foi feita com $1 \mathrm{~V}$ de fenol e $1 \mathrm{~V}$ de álcool isoamílico: clorofórmio (1:24), seguida por centrifugação, por cinco minutos, a $10.000 \mathrm{rpm}$, em microcentrífuga; a fase aquosa era transferida para novos tubos, onde eram adicionados $1 / 10 \mathrm{~V}$ de acetato de sódio a $3 \mathrm{M}$ e mais $2 \mathrm{~V}$ de etanol 100\%. Para precipitação do DNA, as amostras eram deixadas de duas a quinze horas, à temperatura de $-20^{\circ} \mathrm{C}$. Nova centrifugação, a $14.000 \mathrm{rpm}$, por dez minutos, descarte do sobrenadante, e secagem do DNA à temperatura ambiente, ou com a utilização de um Speedvac.

O DNA era, então, diluído em $50 \mu \mathrm{L}$ de água estéril, estando pronto para passar pelos testes de espectrofotometria e PCR.

Como é um método muito utilizado, apresenta muitas variáveis. ${ }^{16,17}$ No caso deste estudo, o método de extração de DNA por digestão com proteinase K, seguida por fenol/clorofórmio, foi alterado com relação ao tampão de digestão (10 mM Tris-HCl, pH 7,5, a 1 M; 10 mM de EDTA, pH 8, a 0,5 M, NaCl a $5 \mathrm{M}$ e SDS a 0,5\%); ao tempo de incubação para digestão - que passou a ser de, no mínimo, 12 horas e, no caso de tecidos parafinizados e bulbos capilares, chegou a 48 horas); e quanto à utilização de fenol e clorofórmio para extração subseqüente.

Alíquotas de $20 \mu \mathrm{L}$ ou concentrações de $1 \mu \mathrm{g}$ de DNA por $100 \mu \mathrm{L}$ de tampão de reação foram utilizadas como template para PCR.

Testes-piloto foram realizados, utilizando-se diretamente o extrato após a digestão pela enzima, sem que houvesse purificação com os solventes orgânicos, ${ }^{2,5}$ mas os resultados não foram conclusivos a ponto de se considerar um método de escolha para este estudo.

Método 2 -digestão por proteinase $K$, sem fenol e clorofórmio

O protocolo foi extraído do Paternity Testing Procedures for Use With the Life Tissues, elaborado pelo FBI e consta de:

Foram acrescentados às amostras pré-tratadas $790 \mu \mathrm{L}$ de tampão de digestão (10 mM Tris- $\mathrm{HCl}, \mathrm{pH}$ 7,5, a $1 \mathrm{M} ; 10 \mathrm{mM}$ de EDTA, pH 8, a 0,5 M, NaCl a $5 \mathrm{M}$ e SDS a $0,5 \%$ ), mais $10 \mu \mathrm{L}$ de proteinase $\mathrm{K}$ a $20 \mathrm{mg} / \mathrm{mL}$. Incubação em banho-maria a $55^{\circ} \mathrm{C}$, por 12 horas. Os debris foram decantados após centrifugação a 12.000 rpm, por dez minutos.
Os sobrenadantes foram transferidos para novos tubos tipo Eppendorf de 2,0 mL, e $400 \mu \mathrm{L}$ de cloreto de lítio a 7,5 M foram acrescentados. A mistura foi colocada em congelador, por trinta minutos, para garantir a precipitação da proteinase K. Nova centrifugação a 14.000 rpm, por 15 minutos, e os sobrenadantes foram colocados em tubos de hemólise estéreis, identificados. Nesses tubos, foram colocados $2 \mathrm{~mL}$ de álcool etílico absoluto, e deixados a $-20^{\circ} \mathrm{C}$ de duas a 24 horas. A centrifugação subseqüente foi a $2.000 \mathrm{rpm}$, por 15 minutos, e os sobrenadantes desprezados, deixando-se aproximadamente, $200 \mu \mathrm{L}$ no tubo para ressuspensão do DNA e sua transferência para tubo tipo Eppendorf de 1,5 mL.

Um mL de álcool etílico a 70\% foi acrescentado, nova centrifugação a $10.000 \mathrm{rpm}$, por cinco minutos, secagem à temperatura ambiente, seguida de diluição em 50-100 $\mu \mathrm{L}$ de água estéril.

No caso de amplificação positiva, foi testado se após purificação com InstaGene Matrix ${ }^{\circledR}$ mudaria os resultados.

\section{Método 3 -fervura em resina quelante Chelex $100 \AA$} (BioRad):

A resina Chelex 100® como método de extração de DNA $^{2,18}$ quela íons que são catalisadores na quebra do DNA, e é possível que se ligue a outras substâncias como produtos derivados do sangue - que inibam a PCR. ${ }^{19}$

Nesse trabalho, a extração foi feita incubando em banho-maria, a $56^{\circ} \mathrm{C}$, amostras de tecido (após desparafinização) e de lâminas de hemograma não coradas, com $100 \mu \mathrm{L}$ dessa resina, a 5\%, por trinta minutos, em seguida, fervura em banho-maria, por oito minutos (inativação) e centrifugação a $14.000 \mathrm{rpm}$, por cinco minutos. Alíquotas de $20 \mu \mathrm{L}$ foram utilizadas para amplificação. ${ }^{20}$

Chelex 100® (Bio Rad) é uma resina que vem em pó, necessitando ser diluída antes do uso. Além disso, a diluição tem que ser feita com, no máximo, uma semana de antecedência; após esse prazo, sua atividade é prejudicada e a confiabilidade nos resultados, diminuída (observado em testes-piloto).

Outras resinas quelantes estão disponíveis no mercado. Uma delas, a InstaGene Matrix ${ }^{\circledR}$, da BioRad.

\section{Método 4 - fervura em resina quelante InstaGene} Matrix (BioRad)

A resina InstaGene Matrix ${ }^{\circledR}$ (Bio Rad) já vem diluída, pronta para uso e estava sendo testada no Laboratório de Biologia Molecular do Hemocentro de Botucatu, para a extração de DNA de tecidos tumorais. A extensão de seu uso para materiais de arquivo e fontes escassas de DNA foi considerada o quarto método nesta pesquisa, mesmo não sendo descrita tal utilidade em sua bula.

Nas amostras pré-tratadas dentro de tubos tipo Eppendorf de 1,5 mL, eram colocados $20 \mu \mathrm{L}$ de água esté- 
ril, e após, $200 \mu \mathrm{L}$ de InstaGene Matrix ${ }^{\circledR}$, não deixando de agitar o frasco da resina, durante a pipetagem. Os demais passos seguiram as recomendações dos fabricantes e $40 \mu \mathrm{L}$ do sobrenadante foram utilizados como template para as PCRs (quantidade estipulada através de testespiloto)

\section{Método 5 - fervura em água estéril ${ }^{2}$}

As amostras pré-tratadas foram fervidas em banhomaria em $100 \mu \mathrm{L}$ de água estéril, por dez minutos. A amostra fervida era adicionada diretamente ao tampão de PCR, sendo usados $50 \mu \mathrm{L}$ como template.

Os testes dos métodos de extração de DNA partiram dos métodos mais simples, rápidos e de menor custo, para os mais complexos, assim eliminando testes desnecessários, caso bons resultados já fossem obtidos.

\section{Avaliação dos métodos de extração}

Além das análises quantitativas, feitas por espectrofotometria, a qualidade do DNA obtido foi avaliada utilizando-o como template em reações de PCR para três fragmentos gênicos de tamanhos diferentes: preferencialmente, iniciava-se pela tentativa de amplificação para Brainderived neutrophic factor (BDNF) de 764 pb; não amplificando, passavam-se para testes com Factor V Leiden (FV) de 220 pb e, em caso de não amplificação, para Abelson (ABL), protooncogene localizado no cromossomo 9, de $106 \mathrm{pb}$

A mistura de reação para amplificação de BDNF consistiu em: $100 \mathrm{mM}$ de primers BDNF-1 (5' AUG GAGAUC CCU GGATCCATGACC ATC CTT TTC CTT 3') e BDNF2 (ACG CGU ACU AGU GGA TCC CCT TTT AAT 3'); $200 \mu \mathrm{M}$ de desoxinucleotídeos; 2,5 U de Taq DNA polimerase (Pharmacia ${ }^{\circledR}$ ); $20 \mathrm{mM}$ Tris- $\mathrm{HCl}$ e 1,5 mM MgCl .

Após a preparação da reação, a amplificação em termociclador (Perkin-Elmer®) para o segmento BDNF será em quarenta ciclos, com temperatura de desnaturação de $94^{\circ} \mathrm{C}$ por 45 segundos, anelamento a $55^{\circ} \mathrm{C}$ por trinta segundos e extensão a $72^{\circ} \mathrm{C}$ por noventa segundos. Extensão final a $72^{\circ} \mathrm{C}$ por dez minutos.

Para amplificação de FV, a mistura de reação foi 400 ng de primers FV1 (5' CTTAAGGAAATGCCCCATTA 3') e FV2 (5' CCA TGC TTAACAAGACCA); 0,2 $\mu \mathrm{M}$ de desoxinucleotídeos; 2,5 U de Taq DNA polimerase (Pharmacia $\left.{ }^{\circledR}\right)$; tampão Tris- $\mathrm{HCl}(\mathrm{pH} 7,5)$ a 10 mM, KCl a 50 mM e $\mathrm{MgCl}_{2}$ a $1,5 \mathrm{mM}$.

A reação de amplificação foi realizada em 35 ciclos, com desnaturação a $94^{\circ} \mathrm{C}$, por 40 segundos, anelamento a $57^{\circ} \mathrm{C}$, por quarenta segundos e extensão a $72^{\circ} \mathrm{C}$, por dois minutos. Os cilos foram precedidos por desnaturação inicial a $94^{\circ} \mathrm{C}$, por sete minutos e sucedidos por extensão final a $72^{\circ} \mathrm{C}$, por sete minutos.

Caso fosse necessária, a amplificação para o gene $\mathrm{ABL}$, a mistura para sua reação era: $150 \mathrm{nM}$ de primers $\mathrm{abl}^{2}$
(5' ATC TCC ACT GGC CACAA 3') e c- abl (5' AGT GAA GCC GCT CGT T 3'); $400 \mu \mathrm{M}$ de desoxinucleotídeos; $1 \mathrm{U}$ de Taq DNA polimerase (Pharmacia ${ }^{\circledR}$ ); $20 \mathrm{mM}$ Tris- $\mathrm{HCl}$ (pH 8,4); $50 \mathrm{mM}$ de $\mathrm{KCl}$ e 1,5 $\mathrm{mM} \mathrm{MgCl}_{2}$.

A PCR para esse segmento era em 35 ciclos, com temperatura de desnaturação de $94^{\circ} \mathrm{C}$ por 25 segundos, anelamento a $49^{\circ} \mathrm{C}$ por 30 segundos e extensão a $72^{\circ} \mathrm{C}$ por um minuto. Extensão final a $72^{\circ} \mathrm{C}$ por dez minutos.

\section{Eletroforese e visualização}

Para amplicons dos fragmentos dos genes BDNF e $\mathrm{FV}$, foram utilizados géis de agarose em concentrações de $3,0 \%$ e 1,5\%, com diluição feita em tampão TEB $0,5 \mathrm{X}$, por aquecimento em forno microondas. As corridas eletroforéticas foram feitas a $80-120 \mathrm{~V}$ por 30-50 minutos em tampão TEB $0,5 \mathrm{X}$.

Quando os resultados foram inconclusivos, ou havia necessidade de amplificação com gene $\mathrm{ABL}$, a eletroforese foi feita em gel de poliacrilamida 4-6\%.

Após a eletroforese, o gel era corado com brometo de etídio e visualizado em luz U.V.

\section{Resultados}

\section{Resultados de Espectrofotometria}

Quanto às quantidades de DNA obtidas com cada método de extração, determinou-se que os resultados espectrofotométricos não são parâmetros confiáveis para direcionar os procedimentos técnicos de extração, pois, mesmo quando as medidas espectrofotométricas não revelavam a presença de DNA, havia, no entanto, amplificação bem sucedida do fragmento esperado.

\section{Resultado de Amplificação por PCR}

Para cada uma das fontes de DNA propostas, dentro de cada um dos diferentes métodos de extração, foram feitos dez testes de extração. Os resultados obtidos com as amplificações do DNA extraído de materiais de arquivo e de fontes escassas estão reunidos na tabela 1 .

Os resultados com o DNA extraído de materiais de arquivo apontam para as seguintes aplicabilidades:

1 - Tecido incluído em parafina: métodos 1, 2, 4 e 5, quando o fragmento gênico tem cerca de $220 \mathrm{pb}$, como o fragmento $\mathrm{FV}$.

2- Hemograma não corado: métodos 3,4 e 5, para fragmentos em torno de $764 \mathrm{pb}$, como o fragmento BDNF (e, conseqüentemente, menores); método 2, seguido por purificação com InstaGene ${ }^{\circledR}$, para 220 pb .

No caso dessas amostras, o DNA extraído pelo método 2 não obteve sucesso em nenhuma amplificação testada, mas, após purificação com InstaGene Matrix ${ }^{\circledR}$ (BioRad), observou-se que o DNA passava a amplificar para o segmento gênico de FV, mas continuava não amplificando para BDNF. 
Tabela 1

Resumo dos resultados obtidos nos testes de amplificação para cada um dos segmentos gênicos utilizados (BDNF, FV e ABL), tendo em vista o método de extração empregado e a fonte potencial de DNA

\begin{tabular}{|c|c|c|c|c|c|c|c|c|c|c|c|c|c|c|c|}
\hline \multicolumn{3}{|c|}{ Método 1} & \multicolumn{3}{|c|}{ Método 2} & \multicolumn{3}{|c|}{ Método 3} & \multicolumn{3}{|c|}{ Método 4} & \multicolumn{3}{|c|}{ Método 5} & \multirow[b]{2}{*}{ Amostras } \\
\hline BNDF & $\mathrm{FV}$ & $A B L$ & BNDF & FV & $A B L$ & BNDF & FV & $A B L$ & BNDF & $\mathrm{FV}$ & $A B L$ & BNDF & FV & $A B L$ & \\
\hline & & & & & & & & & & & & & & & Material de Arquivo: \\
\hline $0 / 10^{*}$ & $10 / 10$ & - & $0 / 10$ & $10 / 10$ & - & $0 / 10$ & $6 / 10$ & $0 / 4$ & $0 / 10$ & $9 / 10$ & $1 / 1$ & $0 / 10$ & $10 / 10$ & - & Tecido parafinizado \\
\hline- & - & - & $0 / 10$ & $0 / 10$ & $0 / 10$ & $9 / 10$ & $1 / 1$ & - & $8 / 10$ & $1 / 2$ & - & $9 / 10$ & $1 / 2$ & - & Lâmina não corada \\
\hline $0 / 10$ & $0 / 10$ & - & $8 / 10$ & $2 / 2$ & - & - & - & - & $2 / 10$ & $5 / 8$ & $0 / 3$ & $0 / 10$ & $7 / 10$ & $3 / 3$ & Lãmina corada \\
\hline $0 / 10$ & $0 / 10$ & $0 / 10$ & $0 / 10$ & $2 / 10$ & $0 / 10$ & - & - & - & $5 / 10$ & $5 / 5$ & - & $0 / 10$ & 1010 & - & Sangue em Card \\
\hline- & - & - & - & - & - & - & - & - & $2 / 3$ & $1 / 1$ & - & - & - & - & Mielograma \\
\hline
\end{tabular}

Fontes escassas:

\begin{tabular}{ccccccccccccccccc}
$10 / 10$ & - & - & $2 / 10$ & $8 / 10$ & - & - & - & - & $0 / 10$ & $10 / 10$ & - & - & - & - \\
$9 / 10$ & $1 / 1$ & - & $8 / 10$ & $2 / 2$ & - & - & - & - & $4 / 10$ & $6 / 6$ & - & - & - & - & 3 bulbo \\
$0 / 10$ & - & - & $10 / 10$ & - & - & - & - & - & $5 / 10$ & $5 / 5$ & - & $1 / 10$ & - & - \\
$5 / 5$ & $5 / 5$ & - & $1 / 10$ & $0 / 9$ & - & - & - & - & $8 / 10$ & $2 / 2$ & - & - & - & - & \\
\hline
\end{tabular}

* Nas frações, o numerador representa o número de amplificações por PCR positivas, enquanto o numerador, o número de testes feitos

3 - Hemograma corado com Leishman: método 2, para $764 \mathrm{pb}$; métodos 4 e 5 , para $220 \mathrm{pb}$. O DNA extraído dessas fontes através do método 1 e a fervura em água estéril não foi bem sucedido em nenhuma amplificação. Em eletroforese em gel de agarose $2 \%$ de sete amostras de DNA extraídas de lâminas de hemograma coradas com Leishman, por fervura em água estéril, observou-se que não havia presença de DNA, apenas pontos luminosos onde o corante se depositara.

4 - Gotas de sangue em Guthrie card: para 764 pb, apenas o método 4 (50\% de sucesso na amplificação); métodos 4 e 5 para 220 pb, assim como métodos 1 e 2 , com purificação posterior pelo método 4. As gotas de sangue em Guthrie Card também apresentaram resultados de amplificação para o segmento de $764 \mathrm{pb}$, todos negativos, quando a extração deu-se por digestão com proteinase K, seguida de fenol e clorofórmio (método 1); após tratamento com InstaGene Matrix ${ }^{\circledR}$, as amostras amplificaram apenas para $220 \mathrm{pb}$.

Ainda nos testes com esse tipo de fonte de DNA, tem-se que a extração através do método 2 também não foi bem sucedida com relação às amplificações por PCR; entretanto, quando esses extratos foram pós-purificados com InstaGene Matrix ${ }^{\circledR}$, oito amostras de dez testes tiveram sucesso na amplificação para o segmento de 220 pb, mas o resultados permaneceram negativos para $764 \mathrm{pb}$.

No caso de gotas de sangue em Guthrie Card e das de lâminas de hemograma não coradas, foi testado se hemólise prévia influiria nos resultados de amplificação, principalmente quando os métodos de extração de DNA empregados eram 1 e 2 . Em ambos os casos, esse pré-tratamento não teve influência.
De acordo com os resultados, foi possível determinar quais os métodos mais indicados para a extração de DNA das três fontes escassas utilizadas neste estudo:

5 - Um bulbo capilar: para 764 pb, o método 1; para $220 \mathrm{pb}$, métodos 4 e 2 .

6 - Três bulbos capilares: para 764 pb, os métodos 1 e 2; para $220 \mathrm{pb}$, os métodos 1, 2 e 4.

Os testes demonstraram que, quando é utilizado apenas um bulbo capilar como fonte de DNA, para fragmentos gênicos de 764 pb, o método 1 de extração é o melhor de todos os testados neste trabalho, mas, para três bulbos capilares, além do método 1 , o método 2 também é viável para este fragmento.

Para os fragmentos gênicos de 220 pb, não importando o número de bulbos disponíveis, o método 4 é bem sucedido na obtenção de DNA amplificável por PCR.

7 - Swab bucal: para 764 pb, o método 2, método 4 ( $50 \%$ de sucesso na amplificação) e método 1 com purificação por InstaGene Matrix ${ }^{\circledR}$. Todos métodos aqui citados também são úteis para 220 pb.

Nessas fontes escassas de DNA observaram-se resultados negativos na amplificação do DNA extraído pelo método 1 para fragmento de 764 pb e, após tratamento com InstaGene Matrix ${ }^{\circledR}$, nove dessas mesmas amostras tiveram amplificações positivas para o mesmo fragmento e para o fragmento de $220 \mathrm{pb}$. Isso já não foi necessário para o DNA extraído pelo método 2, onde todos amplificaram para $764 \mathrm{pb}$.

Quanto à fervura em água estéril de células bucais para extração de DNA, apenas 1 amplificou para BDNF, e para FV só foi observada amplificação após passar as amostras por purificação com InstaGene Matrix ${ }^{\circledR}$. 
A utilização de swabs para coleta de células bucais, mostrou ser um método prático, pouco invasivo e útil para coleta de DNA amplificável por PCR.

Quando a extração de DNA foi feita apenas com InstaGene Matrix ${ }^{\circledR}$, obteve-se $50 \%$ de sucesso na amplificação de 764 pb, tornando-se, então, um método de extração de DNA mais adequado para fragmentos tão pequenos quanto o do gene para $220 \mathrm{pb}$.

Dos testes realizados com amostras fervidas em água estéril, obteve-se apenas um resultado de amplificação positiva para $764 \mathrm{pb}$. As amostras apenas se tornaram positivas para $220 \mathrm{pb}$, após passarem por purificação com InstaGene Matrix ${ }^{\circledR}$.

8 - Urina: para 764 pb, método 4; para 220 pb, métodos 1, 4 e 2 com purificação com InstaGene Matrix ${ }^{\circledR}$.

As cinco amostras de amplificação negativa do DNA extraído através do método 1 , assim continuaram, mesmo após purificação com InstaGene Matrix ${ }^{\circledR}$. No caso das amostras negativas do método 2 , após o mesmo tratamento, mais duas amplificaram para fragmento de $764 \mathrm{pb}(3 / 10)$ e 7/10 amplificaram para fragmento de $220 \mathrm{pb}$.

\section{Discussão}

Neste trabalho, observou-se que, para tecidos incluídos em parafina, o método de extração de DNA escolhido tem influência menor do que o tamanho do fragmento gênico a ser amplificado através da técnica de PCR, pois todos os métodos de extração testados aqui foram eficientes na amplificação de fragmento de $220 \mathrm{pb}$, mas nenhum obteve sucesso na amplificação de fragmento de 764 pb.

Assim como em Kullmann et $\mathrm{al}^{21}$ e Liu e seus colaboradores, ${ }^{22} \mathrm{o}$ fator influente no sucesso na amplificação do DNA obtido de tecido incluído em parafina é o grau de fragmentação do DNA presente nessas amostras. Falhas encontradas podem também não ser apenas devido à ausência das seqüências-alvo pesquisadas, mas, sim, um efeito direto do fixador, tempo e/ou temperatura de fixação utilizados no processamento dessas amostras nos serviços de Patologia.

Como sugerido por Shibata et al, ${ }^{18}$ os ciclos de amplificação foram aumentados em cinco ciclos, de forma a garantir a amplificação de DNA, caso este estivesse presente e com qualidade para ser amplificado.

Além disso, vários outros passos podem ser modificados para obtenção de amplificações positivas, a começar pela forma de obtenção dos cortes $;{ }^{6}$ a desparafinização que, além de poder ser opcional, ${ }^{7}$ pode ser realizada através de calor ou lavagens com solventes como xilol ${ }^{19}$ e o tempo de digestão em proteinase $\mathrm{K}$ (que pode variar de uma hora a cinco dias) e a concentração desta no tampão de digestão. ${ }^{23}$

De Lamberie ${ }^{24}$ e Sepp ${ }^{2}$ e seus respectivos colaboradores determinaram que o melhor método de extração de
DNA de tecidos incluídos em parafina é aquele equivalente ao método 1 deste trabalho, com purificação posterior por resinas quelantes.

Comparando os resultados da fervura em água estéril para extração de DNA de gotas de sangue em Guthrie Card com aqueles de lâminas de hemograma não coradas, nota-se que os insucessos na amplificação do DNA, quando este foi extraído pelos métodos 1 e 2 , não podem ser explicados pela fragmentação do DNA, já que nenhuma amplificação para $220 \mathrm{pb}$ foi observada e houve amplificações positivas para 764 pb quando outros métodos de extração de DNA foram utilizados.

Por se tratarem de amostras com sangue periférico, cuidados foram tomados com relação aos inibidores de PCR, pois, segundo Gribben e colaboradores, ${ }^{17}$ a hemoglobina pode inibir a reação, já que os íons $\mathrm{Fe}++$ são competidores dos íons $\mathrm{Mg}++$, necessários à ação da DNA polymerase. Tais inibidores parecem ser resistentes à fervura, não destruídos por proteinases, não solúveis em solventes orgânicos e possuírem um peso molecular menor que 10 quilodáltons $(\mathrm{kD}){ }^{5}$

A presença de inibidores de PCR nas amostras com sangue seria uma justificativa perfeitamente plausível, não fossem os resultados positivos nas amplificações de amostras, cujas extrações de DNA deram-se por fervura em água estéril, que apenas não foi útil em lâminas de hemograma coradas com Leishman, aí sim, devido provavelmente à presença de inibidores.

Buscando uma resposta para os resultados negativos na amplificação de DNA extraído dessas amostras através dos métodos 1 e 2 , suas amostras foram pós-tratadas com InstaGene Matrix ${ }^{\circledR}$, de forma a buscar eliminar a possível presença de inibidores, e os resultados de amplificação passaram a ser positivos para 220 pb, mas não de $764 \mathrm{pb}$ ou qualquer um dos dois, nas amostras do método 1 .

No primeiro caso, fica sugerido que InstaGene Matrix ${ }^{\circledR}$ purificou as amostras, o que não aconteceu quando o método de extração de DNA incluiu fenol e clorofórmio. Novos estudos envolvendo inibidores de PCR devem ser realizados para esclarecer os fatos observados, inclusive o da obtenção de amplificação positiva de 764 pb em DNA extraído pelo método 2 de lâmina de hemograma corada com Leishman.

Quando os testes foram realizados com lâminas de hemogramas não coradas, observaram-se que os resultados na amplificação de DNA extraído com Chelex 100®, não foram muito diferentes daqueles com InstaGene ${ }^{\circledR}$ resultado também observado no caso de tecido incluído em parafina - e foi optado por cessarem os testes com a primeira resina, pois a segunda era mais prática por se apresentar diluída.

De acordo com testes-piloto realizados em 1996, no Laboratório de Biologia Molecular do Hemocentro de Botucatu, lâminas de mielograma também caracterizaram 
boa fonte de DNA para amplificação por PCR, mesmo que tenham sido usados os métodos 3, 4 ou 5 de extração, havendo maior destaque ao método 4 .

Com relação aos bulbos capilares, foi decidido por testes com apenas um e com três bulbos, para verificar qual seria a possível influência da quantidade de material na amplificação por PCR. Anteriormente aos testes finais, foram realizados testes-piloto com extração de DNA pelo método 4 e, nestes, ficou sugerido que o número de bulbos não influenciaria negativamente na amplificação para 220 pb, mas sim para 764 pb, quando esse método de extração fosse utilizado. Além disso, como template para a PCR, poderiam ser utilizados tanto os $40 \mu \mathrm{L}$ padronizados, como $1 \mu \mathrm{g}$ de DNA/ $100 \mu \mathrm{L}$ de reação.

Outros testes mostraram que a lavagem prévia com solução TKM-1 pareceu influenciar positivamente na obtenção de DNA amplificável por PCR.

Observando-se os bons resultados na amplificação do fragmento de 764 pb no DNA extraído de células bucais através do método 2 , tem-se que a técnica oferece DNA em quantidade suficiente e de alto peso molecular. $\mathrm{O}$ método 1, opondo-se ao método 2, não ofereceu DNA amplificável para tal fragmento, o que ocasionou a necessidade de outra purificação dos extratos, desta vez com a resina InstaGene Matrix ${ }^{\circledR}$, para que as amplificações de $764 \mathrm{pb}$ se tornassem positivas, demonstrando que a utilização de solventes orgânicos, pode proporcionar o surgimento de substâncias inibidoras de PCR, assim como o ocorrido com as amostras de sangue periférico em lâmina de hemograma e em Guthrie Card.

Embora alguns autores descrevam o acréscimo direto da saliva na PCR, ${ }^{25}$ sugere-se aqui que seja adotado o uso de, pelo menos, uma resina quelante, para que seja potencializada a possibilidade de obtenção de resultados mais seguros de amplificação. A utilização de digestão por proteinase $\mathrm{K}$, sua inativação a $100{ }^{\circ} \mathrm{C}$, seguida por purificação com resinas quelantes, não deve ser descartada como método de extração passível de novos testes.

Alíquotas de $2 \mathrm{~mL}$ de urina total foram as últimas fontes escassas de DNA consideradas neste estudo. Os resultados dos testes de amplificação demonstraram que o método de escolha para extração de DNA de tais amostras é o de $\mathrm{n}^{\mathrm{o}} 4$, sendo que o método 1 é válido na obtenção de amplificação de fragmentos gênicos menores.

Morre e colaboradores ${ }^{26}$ ainda assinalaram que, se a urina for deixada à temperatura ambiente por cinco a sete dias, seu DNA sofreria degradação e que o mesmo não ocorre, caso ela seja estocada a $4{ }^{\circ} \mathrm{C}$, como foi feito neste estudo.

\section{Conclusão}

Alguns dos métodos testados e padronizados através deste trabalho, já foram utilizadas em outros do mes- mo laboratório. Barrach et $\mathrm{al}^{27}$ utilizaram extração de DNA de gotas de sangue colhidas em Guthrie Card através do método 4 para pesquisa sobre identificação de predisposição genética para trombose venosa, na qual o DNA amplificado por PCR ainda passava por digestão pela enzima de restrição MnlI, antes da determinação dos padrões eletroforéticos esperados. Toralles-Pereira ${ }^{28}$ utilizou células bucais colhidas com swab como fonte de DNA, que foi obtido também através do método 4, para desenvolver estudo sobre polimorfismo de antígenos plaquetários.

Os resultados desta pesquisa contribuem com a melhoria da qualidade e confiabilidade da técnica de PCR quando as amostras citadas forem utilizadas, permitindo maior segurança e aproveitamento das amostras, bem como economia de tempo e gastos.

\begin{abstract}
The present work aimed at comparing five different methods of DNA extraction of samples from archived materials (paraffinembedded tissues, peripheral blood smears - stained or not with Leishman, aspired bone marrow smears and Guthrie card bloodspots) and from rare sources (oral cells, one and three capillary bulbs, $2 \mathrm{~mL}$ of urine), to evaluate the ease of application and the possibility of amplification of this DNA by the polymerization chain reaction (PCR) technique. The methods included proteinase $K$ digestion - followed or not by phenol/ chloroform purification, Chelex $100 \AA$ (BioRad), InstaGene ${ }^{\circledR}$ (BioRad) and boiling in the sterile water. The DNA obtained was tested for amplification of three genic fragments: the brain-derived neutrophic factor gene (764 bp), the Factor V Leiden gene (220 $b p$ ) and the Abelson gene (106 bp). According to the gene fragment length studied, the DNA potential source and the extraction method used, the results characterized the best way to standardize technical procedures to be included in the Standard Operational Procedure Manual of the Molecular Biology Laboratory of the Blood Center in the Medicine School of Unesp, Botucatu, Brazil. Rev. bras. hematol. hemoter. 2004;26(4):274-281.
\end{abstract}

Key words: Archived material samples; rare sources; DNA extraction; $P C R$

\section{Referências Bibliográficas}

1. Saiki RK, Gilfand DH, Stoffel S et al. Primer-directed enzymatic amplification of DNA with a termoestable DNA polymerase. Science 1988;239:487.

2. Sepp S, Szabó I, Uda H, Sakamoto H. Rapid techniques for DNA extraction from routinely processed archival tissue for use in PCR. J Clin Pathol 1994;47:318.

3. Perkins SL, Kjeldsberg CR. Immunophenotyping of lymphomas and leukemias in paraffin-embedded tissues. Am J Clin Pathol 1993;99:362.

4. Provan AB, Hodges E, Smith AG, Smith JL. Use of wax embedded bone marrow trephine biopsy specimens as a source of archival DNA. J Clin Pathol 1992;45:763. 
5. An SF, Fleming KA. Removal of inhibitors of the polymerase chain reaction from formalin fixed, paraffin-wax embedded tissues. J Clin Pathol 1991;44:924.

6. Chen BF, Clejan S. Rapid preparation of tissue DNA from paraffin-embedded blocks and analysis by polymerase chain reaction. J Histochem Cytochem 1993;41:765.

7. Coats PJ, d'Artenne AJ, Khan G et al. Simplified procedures applying the polymerase chain reaction to routinely fixed paraffin-wax sections. J Clin Pathol 1991;44:115.

8. Harnett PR, Greenberg ML, Tattersall MH et al. Method of extracting DNA from fine needle aspirates of human solid tumors for Southern blot analysis. Anal Quant Cytol Histol 1989; 11:375

9. Pavelic J, Gall TK, Bosnar MH et al. PCR amplification of DNA from archival specimens. A methodological approach. Neoplasma 1996;43:75.

10. Cassol AS, Read S, Weniger BG et al. Dried blood spots on filter paper: a international resource for the diagnosis and genetic characterization of human immunodeficiency virus type 1 . Mem Inst Oswaldo Cruz 1996;2:124.

11. Makowsk GS, Davis EL, Hopfer SM. The effect of storage on Guthrie cards: implications for deoxyribonucleic acid amplification. Am Clin Lab Sci 1996;25:458.

12. Piazza M, Chirianni A, Luizzi $G$ et al. HIV-1 proviral DNA sequences in the saliva with HIV infection. Boll Soc Ital Biol Sper 1992;68:475

13. Richards B, Skoletsky J, Shuber AP et al. Multiples PCR amplification from the CFTR gene using prepared from buccal brushes/swabs. Hum Mol Genet 1993;2:159.

14. Jacobson DL, Womack SD, Peralta L et al. Concordance of Human papillomavirus in the cervix and urine among inner city adolescents. Ped Infect Dis 2000;19:722.

15. Friedrich MG, Erbersdobber A, Schwaibold $\mathrm{H}$ et al. Detection of loss heterozygosity in the p53 tumor-suppressor gene with PCR in the urine of patients with bladder cancer. J Urol 2000; 163:1.039.

16. Coombs NJ, Gouch AC, Primrose JN. Optimization of DNA and RNA extraction from archival formalin-fixed tissue. Nucleic Acids Res 1999;27:12.

17. Gribben JG, Freedman AS, Woo SD et al. All advanced stage non-Hodgkin's lymphomas with a polymerase chain reaction amplifiable breakpoint of bcl-2 rearrangement at evaluation and after treatment. Blood 1991;78:3.275.

18. Shibata D. Extraction of DNA from paraffin-embedded tissue for analysis by polymerase chain reaction: new tricks for a old friend. Human Pathol 1994;25:561.

19. Ausubel FM et al. Unit 15: The polymerase chain reaction, in Current Protocols in Molecular Biology, Greene Publishing Associates and Wiley-Interscience, New York, 1992.

20. Edwards A et al. Genetic variation at five trimeric and tetrameric tandem repeats loci in four human population groups. Genomics, $1992 ; 12: 241$

21. Kullman F, Bocker T, Schoelmeurich J, Rueschoff J. A comparison of methods for DNA extraction from paraffinembedded tissue for microsatellite instability analysis by PCR. Acta Biotech 1998;18:77.

22. Liu J, Johnson RM, Traweek ST. Rearrangement of the BCL-2 gene in follicular lymphoma. Detection by PCR in both fresh and fixed tissue samples. Diagn Mol Pathol 1993;2:241.

23. Jackson DP, Lewis FA, Taylor GR et al. Tissue extraction of DNA and RNA analysis by polymerase chain reaction. J Clin Pathol 1990;43:499.
24. De Lamberie X, Chapel F, Vignoli C, Zandotti C. Improved current methods for amplification of DNA from routinely processed liver tissue by PCR. J Clin Pathol 1994;47:466.

25. Yamamoto I, Ishizu H. Km genotyping by polymerase chain reaction using allele specific amplification primers. Forensic Sci Int 1995;75:85

26. Morre AS, van Valkengoed IG, de Jong A et al. Mailed, homeobtained urine specimens: a reliable screening approach for detecting asymptomatic Chlamydia trachomatis infections. J Clin Microbiol 1999;37:976.

27. Barrach FH, Barea JA, Sales MM, et al. O laboratório de análises clínicas e a identificação de predisposição genética para trombose venosa. NewsLab 2000;38:96.

28. Toralles-Pereira C. O polimorfismo dos antígenos plaquetários. Botucatu, 2001. 110p. Dissertação (Mestrado) - Faculdade de Medicina, Universidade Estadual Paulista.

Atuaram na avaliação o Prof. Maurício Lacerda Nogueira como editor associado e dois revisores externos e publicado após concordância do editor.

Conflito de interesse: não declarado

Recebido: 20/10/2004

Aceito após modificações: 06/12/2004 